\title{
VARIATION OF SEED PRODUCTION AND VIABILITY IN A FULL-SIB TRIAL OF Melaleuca cajuputi sub sp. cajuputi IN GUNUNGKIDUL YOGYAKARTA
}

\author{
Liliana Baskorowati $^{1,2}$, Mudji Susanto ${ }^{1}$, Prasetyono ${ }^{1}$, \\ Noor Kartikawati ${ }^{1}$ and Anto Rimbawanto ${ }^{1}$ \\ Received : 16 March 2012, Accepted : 26 October 2012
}

\begin{abstract}
Family variation of capsule production and the seed viability in the Paliyan full-sib trial of Melaleuca cajuputi subsp. cajuputi, at Gunungkidul, Yogyakarta, were observed. The full-sib trial was designed as Incomplete Block Design, consisting of 39 families; six individual as tree plot and replicated in eight blocks. Height and diameter at breast height were assessed to identify the correlation between capsule category and growth performance. The capsule production was assessed visually to one of the capsule categories: "0" for none; " 1 " for light; " 2 " for medium and " 3 " for heavy. Results showed that each family of $M$. cajuputi sub sp. cajuputi equally contributed to the seed production. Progeny analysis showed that the seed productions were not strongly under genetic control $\left(h^{2} i\right)=0.12$. This study also found positive correlation between the flowering strength (the flower production levels) and the number of capsule $\left(R^{2}=0.279\right)$. However, there were no significant differences between the flowering levels and the viability of $M$. cajuputi sub sp. cajuputi. Mean seed viability was $31 \%$, there were no significantly differences of capsules production between trees having high flowering intensity and low flowering intensity. Low seed viability was assumed due to the unsynchronicity of flowering, leading to the low levels of outcrossing rate. Therefore, selection of families with synchronicity of flowering was recommended to establish a seed orchard.
\end{abstract}

Keywords: Seed production, seed viability, Melalenca cajuputi, genetic control, flowering

\section{INTRODUCTION}

Melalenca cajuputi sub sp. cajuputi, commonly known as 'kayuputib', represented by three sub species, is the most widespread species, extending from northern Australia to parts of Papua New Guinea, Indonesia, Malaysia, Thailand, Cambodia and Vietnam (Craven, 1999). In Indonesia this species occurs in Maluku, Seram and Buru islands (Gunn et al., 1997). M.cajuputi sub sp. cajuputi plantations are the main source of cajuput oil industry in Indonesia. Cajuput oil industry is part of forestry activities in Indonesia aimed at producing non-timber forest products as well as a

${ }^{1}$ Centre for Forest Biotechnology and Tree Improvement Research

2Corresponding Author: lbaskorowati@yahoo.com useful prosperity approach for people living around the forest area. Total plantation area of M. cajuputi sub sp. cajuputi is in the order of 24,000 ha concentrated in Java Island with annual production of leaves biomass of $300 t / y$ that are managed by Perum Perhutani. Outside Java, cajuput farmers especially in Buru, Seram, Ambon and Aru islands run their home oil industry by collecting the biomass from natural plantations of $M$. cajuputi sub sp. cajuputi (Rimbawanto et al., 2009).

In response to demand for good seed, Common wealth Scientific and Industrial Research Organization (CSIRO) and Forestry Research and Development Agency (FORDA) have initiated a selection and breeding program for $M$. cajuputi sub sp. cajuputi since 1995 (Doran et al., 1998). To date, several seedling seed orchards and clonal seed 
orchards had been established in Java based on selection; aimed to improve the 1,8-cineole content and improve oil yield. However, more detailed study of seed yield is required to improve seeds collected from seedling seed orchards. Seed production areas and seed orchards exist to produce the greatest possible yield of well-filled viable seed. Their successful management depends on a thorough knowledge of the genetics and physiology of flowering as well as seed production, and it is therefore necessary to investigate the current state of knowledge on these aspects.

Estimating and understanding the amount of seed production of a seed orchard is important. Since the information on the individual and family variation in seed yield is important towards increasing the improved seed, the target may be limited by mating among a few families. It is likely that a lot of seeds will be produced from a few families when the individual and family variation is high in terms of seed production (Yamada et al., 2001).

This study therefore was conducted aimed to evaluate the family variation in capsule production and the subsequentseed viability in Paliyan Fullsib of Melalenca cajuputi sub sp. cajuputi Seedling Seed Orchard, Yogyakarta, Indonesia.

\section{MATERIAL AND METHOD}

\section{A. Material}

Melalenca cajuputi sub sp. cajuputi Full-sib seedling seed orchard was established on December 2004, comprising 39 full sib families, six tree plots with eight replicates and was designed following incomplete block design. First flowering of this plantation occurs in 2006, and the observation of family variation in capsule production was carried out during peak capsule period in September 2009. Meanwhile, the observation of seed germination to determine the seed viability was carried out from November to December 2009.

\section{B. Methods}

Assessment of the traits was conducted on all individual trees in this plot (the number of trees were 1.920s). Height and diameter at breast height were only two quantitative traits included in the assessment to identify the correlation between capsule category and growth performance. Height (Ht) referred to the total tree height, measured to the nearest $0.1 \mathrm{~m}$. Diameter (Dbb) was defined as the stem diameter taken at $1.3 \mathrm{~m}$ from ground level and was measured to the nearest $0.1 \mathrm{~cm}$ (Pinyopusarerk et al., 2004).

Classification and scoring techniques were applied to characteristics which could not be measured quantitatively (Pinyopusarerk et al., 2004). The capsule production was assessed visually to one of the capsule categories (based on flowering categories by Griffin et al., 1992). The scores are: "0" for none; "1" for light; " 2 " for medium and " 3 " for heavy.

Twenty four representative trees were randomly selected from each capsule category one, two and three. The total capsules produced from each of sampled trees were harvested. All capsules were then cleaned from the debris by sieving using one $\mathrm{mm}$ siever, to leave a mixture of seed and chaff; and weighed to record the actual weight of capsules produced by each category. Turnbull and Doran (1987) noted that the majority of myrtaceous species, such as species of Eucalyptus and Melaleuca, have very small seeds of irregular shape, which make it difficult to precisely separate pure seed and chaff. In M. cajuputi sub sp. cajuputi because of the small size of the seeds and because the seed and chaff are the same colour, it was found impossible to reliably separate seed from the chaff even under the microscope, so the entire mixture had to be sown for germination testing.

The seed and chaff of each sample (the content of three capsules each sample) were sprinkled on moist Whatman filter paper over $30 \mathrm{ml}$ of a-grade vermiculite in a $90 \mathrm{~mm}$ glass petridish, to which 28 $\mathrm{ml}$ of gel-filtrated water was added. Dishes totalled 120 (12 trees x 10, 3-capsule samples). These were placed in a germination cabinet set at a constant temperature of $25^{\circ} \mathrm{C}$ with $12 \mathrm{~h}$ of light per day. Germination counts in any dish commenced when the first cotyledons emerged, usually on day four. Healthy germinated seedlings were recorded on a daily basis up to 42 days. Seed viability of each sample was tested by counting the number of germinated seed.

The individual trait related data were analyzed using the ANOVA procedure in Genstat Version 5.3.2 to check for homogeneity of variances 
(Payne et al., 1987). Analyses on the data were based on the following linear model:.

where:

$$
\mathrm{Y}_{\mathrm{ij}}=\mu+\mathrm{R}_{i}+\mathrm{F}_{j}+\mathrm{e}_{i j}
$$

$\mu=$ the overall mean;

$\mathrm{R}_{i}=$ the effect of the replicate

$\mathrm{F}_{j}=$ the effect of the ${ }^{\text {th }}$ Family

$\mathrm{e}_{\mathrm{ij}}=$ the residual error with a mean of zero.

$\mathrm{Y}_{\mathrm{ij}}=$ the plot mean of the $j^{\text {th }}$ family, the replicate

The mean family variance components were used to estimate mean covering individual tree heritability (denoted as $\mathrm{h}_{\mathrm{i}}^{2}$ ) separately for each trait as follows:

$$
h_{i}^{2}=\frac{1}{r} \times \frac{\sigma_{f}^{2}}{\sigma_{p}^{2}}
$$

where:

$\mathrm{h}_{\mathrm{i}}^{2}=$ individual tree heritability

$\mathrm{r}=$ coefficient of relationship

$\sigma_{\mathrm{f}}^{2}=$ variance between families-withinprovenance groups

$\sigma_{\mathrm{p}}^{2}=$ phenotypic variance

$=\left(\mathrm{s}_{\mathrm{f}}{ }^{2}+\mathrm{s}_{\mathrm{m}}{ }^{2}+\mathrm{s}_{\mathrm{t}}{ }^{2}\right)^{2}=$ variance between plots

$\sigma_{t}^{2}=$ variance between trees within plots

The coefficient of relationship among offsprings used in computation of the individual tree heritability was assumed to 0.4 based on the assumption that likes many species of eucalyptus and other members of the family Myrtaceae (Moran, 1992). Genetic correlations (denoted $r_{g}$ ) were calculated according methodologies described by Williams et. al., (2002) based on the following formula:

$$
r_{g}=c_{0 v f}(X, Y) /\left[\sigma_{f}^{2}(x) \cdot \sigma_{f}^{2}(y)\right]^{1 / 2}
$$

where:

$$
\begin{aligned}
& \operatorname{Cov}_{\mathrm{f}}(\mathrm{X}, \mathrm{Y})= \text { covariance of the two traits at the } \\
& \text { family level } \\
& \sigma_{\mathrm{f}}^{2}(\mathrm{x}) \quad \text { family- level variance components } \\
& \text { of trait }(\mathrm{x}) \\
&= \text { family- level variance components } \\
& \text { of trait }(\mathrm{y}) \\
& \sigma_{\mathrm{f}}^{2}(\mathrm{y}) \text { genetic correlations } \\
& \mathrm{r}
\end{aligned}
$$

\section{RESULT AND DISCUSSION}

\section{A. Family Variation, Heritability and Genetic Correlation}

Significant capsules production was found in full-sib seedling seed orchard in which $76.07 \%$ of the total trees contributed to produce capsules during the 2009 fruiting season. Capsule production varied significantly between families $(\mathrm{df}=38 ; \mathrm{MS}=2.293 ; \operatorname{Pr}=<.0001)$, replications, replication and family interactions (see Table 1). Figure 1, illustrated the ability for each family (based on male parent) of $M$. cajuputi in this population to produce capsules, during 2009 fruiting season. This figure showed that several families of male parent no 19,25 and 2a produced more capsules compared to families of male parent number 02,10 and 18 . This variation analysis showed that genotype influenced the ability to produce capsules.

Variation of seed production may occur within and between species (Kramer and Kozlowski, 1960; Matthews, 1963; Jackson and Sweet, 1972). They mentioned that environmental factors i.e. whether conditions, nutrition, and genetic factors i.e. synchronycity of flowering and degree of selfincompatibility of a species in one population have been important attributes to of flower initiation and the production of seed in forest trees. The synchronyous flowering may attract various insects or animal as pollinator to visit and to transfer pollen from one to other trees. This also may increase the pollen transfer between trees leading to increased cross pollination.

Previous study of flowering and fruiting of $M$. cajuputi sub sp. cajuputi in a seedling seed orchard showed that variation of flowering intensity between provenances occurs in population (Baskorowati et al., 2008). Another study of $M$. cajuputi sub sp. cajuputi in a seedling seed orchard in Yogyakarta, found that in general this species has a high level of self-incompatibilty (0.05), although some individual trees were completely self-incompatible (Kartikawati, 2005). These compatibility may result in inbreeding, leading to the reduction of viable seed or vigour of the seed. In this study, there were found variations of seed production between families suggesting that each full-sib family equally 
Table1. ANOVA and heritability of capsule production, height and diameter of M. cajuputi sub sp. cajuputi at full-sib seedling seed orchard Paliyan, in Gunungkidul, Yogyakarta

\begin{tabular}{lrrrrrrr}
\hline & \multicolumn{3}{c}{ Capsule production (score) } & \multicolumn{2}{c}{ Height $(\mathrm{m})$} & \multicolumn{2}{c}{ Diameter $(\mathrm{cm})$} \\
\hline \multicolumn{1}{c}{ Source } & $\mathrm{db}$ & $\mathrm{MS}$ & Prob & MS & Prob & MS & Prob \\
\hline Rep & 7 & 26.825 & $<.0001$ & 46.38 & $<.0001$ & 26.59 & $<.0001$ \\
Fam & 38 & 2.293 & $<.0001$ & 5.21 & $<.0001$ & 3.81 & $<.0001$ \\
Rep*Fam & 181 & \multirow{2}{*}{1.346} & $<.0001$ & 2.09 & $<.0001$ & 2.22 & $<.0001$ \\
\hline \multicolumn{2}{c}{ Heritability $\left(\mathrm{h}^{2} \mathrm{i}\right)$} & \multicolumn{3}{c}{0.12} & \multicolumn{3}{c}{0.14} \\
\hline
\end{tabular}

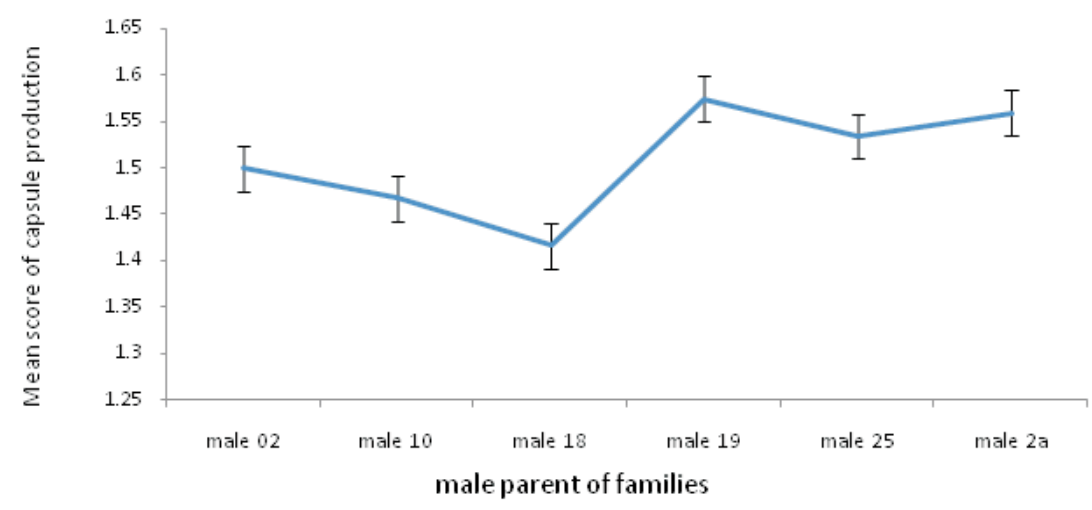

Figure 1. Mean number of capsule production of $M$. cajuputi sub sp. cajuputi grouped by male parent of families

contributed to the seed production. Grouped seed production based on male parent, revealed that seed production varied significantly between male parents; means that the ability of pollen from different mother tress may vary or the degree of self-incompatibility may occurs in this family.

However, the individual heritability of seed production in this study site was medium $\left(\mathrm{h}^{2} \mathrm{i}\right)=$ 0.12; meaning the seed productions were not strongly under genetic control. According to Williams et al. (2002), the medium individual heritability found in this study indicates more environment effect control than that of genetic effect. In general, the seed production is likely to be plastically influenced by internal and environmental condition, pollination, damage by disease and insect pest (Yamada et al., 2001). Moreover, flowering and fruiting of tropical tree species generally were also influenced by season, which not very clear every year.

At this study site, the replication treatment greatly influenced the capsule production; trees in replications/blocks one and two produced more capsules than those in other replications (Figure 2). The significant differences in the capability to produce capsules, which influenced by the flower production between replications were probably influenced by the amount of sunlight (radiation) received by individual trees in this population. In this site, replications one and two are located in the edges of the population, therefore probability of individual trees in these plots receiving sunlight more than other plots.

Estimation of genetic and phenotypic correlation between traits in the full-sib seedling seed orchards of $M$. cajuputi sub sp. cajuputi are presented in Table 2 .

Negative correlations were found between capsule production and growth parameters. Genetic correlation between capsule production vs. height and vs. diameter are $r_{g}=-0.87$ and $r_{g}=-$ 0.25 respectively. Negative correlation in this parameter indicates that they are not possible to simultaneously achieve genetic gain in terms of growth traits and capsule productions. 


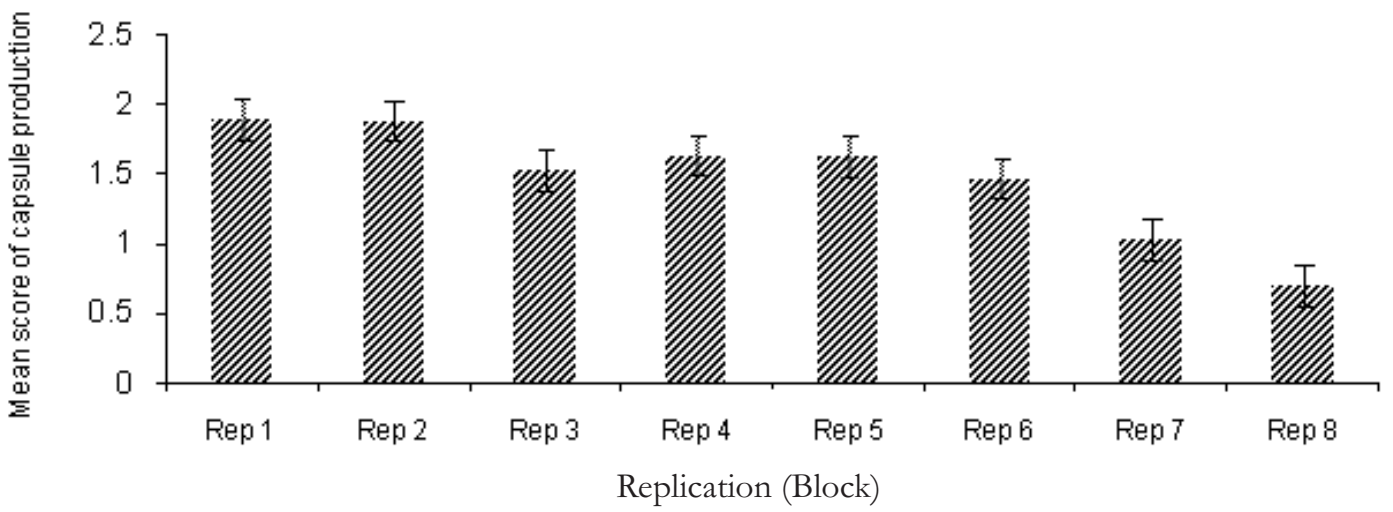

Figure 2. Variation in mean capsule production and associated standard error of $M$. cajuputi sub sp. cajuputi between replications/blocks

Table 2. Estimation of genetic and phenotypic correlation $\left(\mathrm{r}_{\mathrm{g}}\right)$ between capsule production and growth traits (height and diameter). Genetic correlations were shown above the diagonal and phenotypic correlations were shown below the diagonal

\begin{tabular}{|c|c|c|c|}
\hline \multirow{2}{*}{ Trait } & \multicolumn{3}{|c|}{ Genetic correlation $\left(\mathrm{r}_{\mathrm{g}}\right)$} \\
\hline & Capsule production (score) & Height (m) & Diameter $(\mathrm{cm})$ \\
\hline Capsule production & $*$ & $-0.87(0.41)$ & $-0.25(0.45)$ \\
\hline Height & 0.4 & $*$ & $0.89(0.62)$ \\
\hline Diameter & 0.09 & 0.6 & $*$ \\
\hline
\end{tabular}

\section{B. Relationship Between Flowering Strength and Actual Number of Capsules}

Results showed that positive correlation between the flowering strength (the flower production) and the number of capsule $\left(\mathrm{R}^{2}=0.279\right)$ were observed. In general, seed production depends upon supply of quality pollen, which will be reduced with lower mating partner density and lower frequency of mate's relatives to other species (Kunin, 1997; Bosh and Waser, 1999; Cunningham, 2000; Duncan et al., 2004). Therefore, increasing of flower production will lead to the capsule production. Even though, pollinator behavior may further affect pollen supply in a population.

Furthermore, plant breeding systems were also characterized as factor affecting seed production. Generally, outcrossing plants are likely to be impacted more than those of self-compatible plants. Melaleuca generally is preferentially outcrossing; for example M. alternifolia, and M. cajuputi sub sp. cajuputi (Butcher et al., 1992; Rosseto et al., 1999; Doran and Moran, 2002; Kartikawati, 2005;

Baskorowati et al., 2010). A study of M. cajuputi sub sp. cajuputi found that in general has a high level of self-incompatibility (0.05) (Kartikawati, 2005). Generally, self-pollination usually results in a reduction in fruit and/or seed production, or reduced seedling vigor (House, 1997; Baskorowati et al., 2010).

\section{Seed Viability}

The seed viability of $M$. cajuputi sub sp. cajuputi was not significantly different between flowering intensity levels $(\mathrm{df}=2 ; \mathrm{MS}=1.49 ; \mathrm{Pr}=0.67)$ and/or among families sample ( $\mathrm{df}=31$; $\mathrm{MS}=$ 5.414; $\operatorname{Pr}=0.088)$. Mean seed viability was $31 \%$; in which capsules produced from trees of high flowering intensity did not differ significantly with capsules produced from trees of low flowering intensity (see Figure 4). 


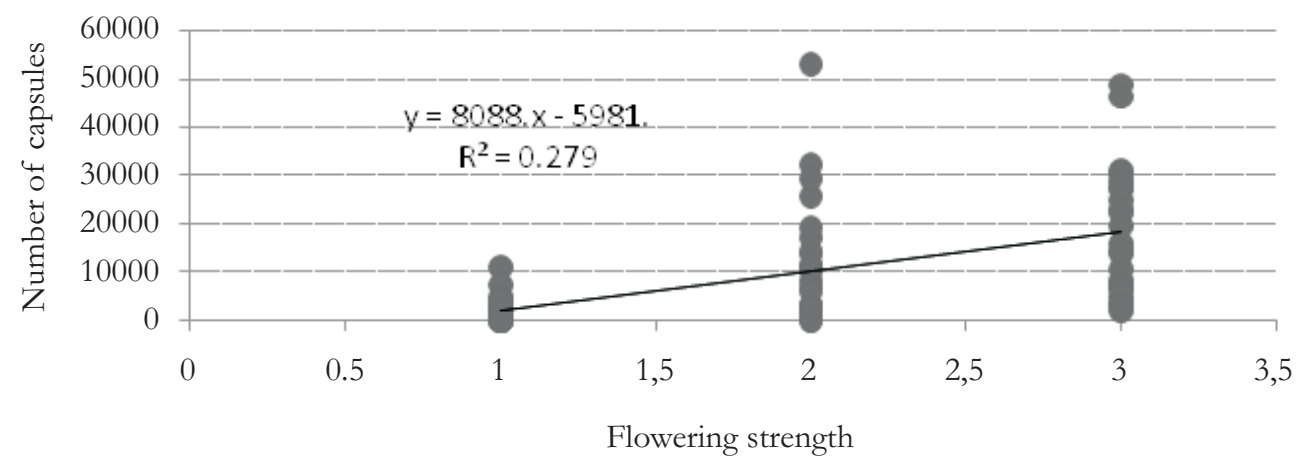

Figure 3. Effect of flowering intensity on the capsule production

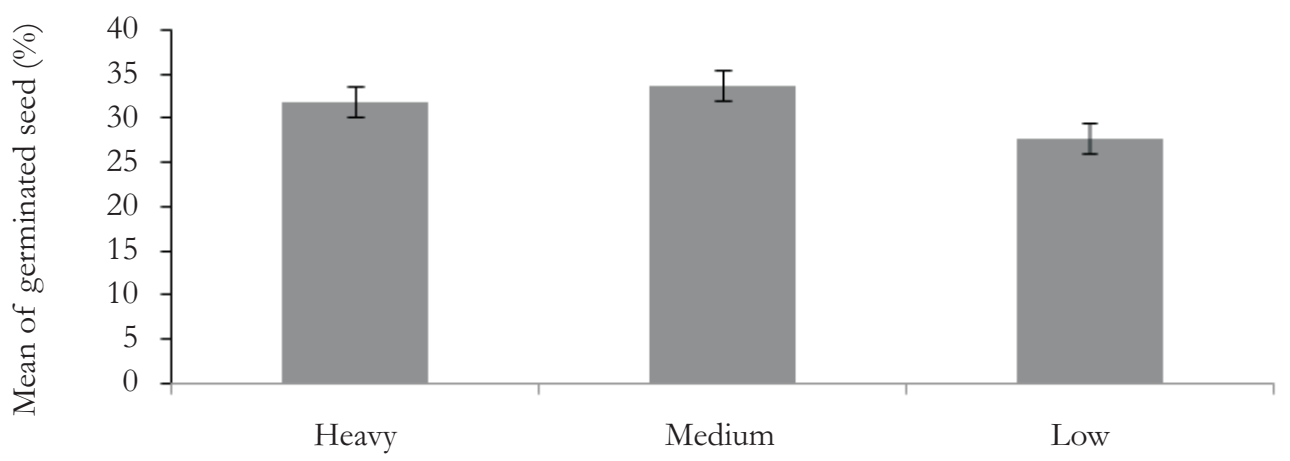

Flowering intensity levels

Figure 4. Mean percentage and associated standard errors of germinated seed per flowering intensity levels

This study therefore indicated that the viability of $M$. cajuputi sub sp. cajuputi from the full-sib trial at Gunungkidul, Yogyakarta population was low, at only 31\%. Previous study of reproductive success of this species found that the reproductive success of $M$. cajuputi sub sp. cajuputi of open pollinated seed is 32\% - 36\% (Hendrati et al., 2002; Baskorowati et al., 2008). Weins et al., (1987) in Owen et al., (1991) informs that in general outcrossing species have a low reproductive success often below $30 \%$, whereas inbreeding species has a high reproductive success.

Low viability has been found in other population of this species and other species of Melaleuca. Baskorowati et al. (2008), for example, reported viability rates of 6 to $32 \%$ for various provenances of $M$. cajuputi sub sp. cajuputi at a seedling seed orchard. Meskimen (1962) found rates of between $3 \%$ and $28 \%$ viability for $M$. quiquenervia in Northern NSW and Southern Queensland.

Low genetic diversity of the parent populations is widely recognized as a major contributing factor to low viability (Young et al.,1996; Cunningham, 2000). Environmental factors also are hypothesized to significantly influence the ability of seed to germinate by initiating or inhibiting (delaying) germination. If environmental factors such as temperature, salinity, or sediment composition are the main influence on the ability of a seed to germinate, then one logical reason for seeds to not germinate under the optimal conditions would be a lack of viability. 


\section{CONCLUSION}

This study revealed that each family of $M$. cajuputi sub sp. cajuputi in full-sib seedling trial at Gunungkidul, Yogyakarta equally contributed to the seed production. However in this study site, the seed productions are not strongly under genetic control $\left(h^{2} \mathrm{i}\right)=0.12$. This study found positive correlation between the flowering strength (the flower production levels) and the number of capsule $\left(\mathrm{R}^{2}=0.279\right)$; however, there were no significant differences between the flowering levels and viability of $M$. cajuputi sub sp. cajuputi.

\section{ACKNOWLEDGEMENT}

This research was funded by Australian Centre for International Agricultural Research, Canberra, Australia through John All Wright Returnee Award Program 2009 awarded to the author. Technical support was provided by Forest Biotechnology and Tree Improvement Research Institute, Jogjakarta, Indonesia. The author is very grateful to Mrs. Alin Maryanti and Mr. Sukidjan for the field assistance.

\section{REFERENCES}

Baskorowati L., R. Umiyati, N.K. Kartikawati, A. Rimbawanto and M. Susanto. 2008. Pembungaan dan pembuahan Melaleuca cajuputi sub sp. cajuputi Powell. di kebun benih semai Paliyan, Gunungkidul, Yogyakarta. Jurnal Pemuliaan Tanaman Hutan 2 (2): 189-202.

Baskorowati L., M.W. Moncur, S.A. Cunningham, J.C. Doran and P.J. Kanowski. 2010. Reproductive biology of Melaleuca alternifolia (Myrtaceae): 2 incompatibility and pollen transfer in relation to the breeding system Australian Journal of Botany 58(5): 384-391.

Bosch, M. and N.M. Waser. 1999. Effect of local density on pollination and reproduction in Delphinium nuttalianum and Aconitum columbianum (Ranunculaceae). American Journal of Botany 86(6): 871-879.
Butcher, P.A., J.C. Bell, and G.F. Moran. 1992. Patterns of genetic diversity and nature of the breeding system in Melaleuca alternifolia (Myrtaceae). Australian Journal of Botany 40: $365-375$.

Craven, L.A., 1999. Behind the names: the botany of tea tree, cajuput and niaouli. In: Southwell I. and R. Lowe. (Eds.) Tea Tree the Genus Melaleuca, Harwood Academic Publishers, Australia, pp. 11 - 28.

Cunningham, S.A., 2000. What determines the number of seed produced in a flowering event? A case study of Calyptrogyneghies breghtiana (Arecaceae). Australian Journal of Botany 48: 659-665.

Doran, J.C. and G.F. Moran. 2002. Development of DNA markers for breeding of tea tree. A report for the Rural Industries Research and Development Corporation. CSIRO, Canberra, 45 pp.

Doran, J.C., A. Rimbawanto, B.V. Gunn and A. Nirsatmanto. 1998. Breeding plan for Melaluca cajuputi sub sp. cajuputi in Indonesia. Technical Report No. 98/178, CSIRO Forestry and Forest Products, Canberra, Australia, 60 pp.

Duncan, D.H., A.B. Nicotra and S.A. Cunningham. 2004. High self-pollen transfer and low fruit set in buzz-pollinated Dianella revolute (Phormiaceae). Australian Journal of Botany 52:185-193.

Gunn B.V., M.W. McDonald, D. Lea, B. Leksono, and J. Nahusana. 1997. Ecology, seed and leaf collections of Cajuput (Melaleuca cajuputi) from Indonesia and Australia. IPGRI Plant Genetic Resources Newsletter 112:36-43.

Griffin, A.R., C.Y. Wong, R. Wickneswari and E. Chia. 1992. Mass production of hybrid seed of Acacia mangium x Acacia auriculiformis inbiclonal seed orchards. In: L. T. Carron and K. M. Aken. Breeding technologies for tropical acacias (Eds.) ACIAR Canberra, pp. 70-75.

Hendrati, R.L., L. Baskorowati and N. Kartikawati. 2002. Reproductive biology of Melalenca cajuputi sub sp. cajuputi. In: A. Rimbawanto and M. Susanto. (eds.) 
Proceedings International Seminar 'Advances in Genetic Improvement of Tropical Tree Species', Centre for Forest Biotechnology and Tree Improvement, Jogjakarta, Indonesia, pp. $139-143$.

House, S.M., 1997. Reproductive biology of eucalypts. In: J. E. Williams and J. C. Z. Woinarski. (Eds.) Eucalypt Ecology, Cambridge University Press, Cambridge, pp. 30-50

Jackson, D.I. and Sweet, G.B., 1972. Flower initiation in temperate woody plants. Horticultural Abstracts 42: 9 - 24.

Kartikawati, N. K., 2005. Tingkat inkompatibilitas bersilang sendiri pada tanaman kayu putih (The level of self-incompatibility of Melalenca cajuputi sub sp. cajuputi). Jurnal Penelitian Hutan Tanaman, 2:141 - 147.

Kramer, P.J. and T.T. Kozlowski. 1960. Physiology of trees. Mc Grow Hill Book Company, New York, $624 \mathrm{pp}$.

Kunin, W.E., 1997. Population size and density effects in pollination: Pollinator foraging and plant reproductive success in experimental arrays of Brassia kaber. The Journal of Ecology 85: 225 -234.

Mathews, J. D., 1963. Factors effecting the production of seed by forest trees. Forestry Abstracts 24: i-xiii.

Meskimen, G.F., 1962. A silvical study of the Melaleuca quinquenervia tree in South Florida. Gainesville, Florida: University of Florida. 177 pp.

Moran, G.F., 1992. Patterns of genetic diversity in Australia tree species. New Forests 6: 49 - 66.

Owen, J. N., P. Sornsathapornkul and S. Tangmitcharoen. 1991. Manual Studying Flowering and Seed Ontogeny in Tropical Forest Trees, ASEAN-Canada, Forest Tree Seed Centre Project, Muak Lek Saraburi, Thailand, $134 \mathrm{pp}$.

Payne, R.W., P.W. Lane, A.E. Ainsley, K.E. Bicknell, P.G.N. Digby, S.A. Harding, P.K. Leech, H.R. Simpson, A.D. Tood, P.J. Verrier, R.P. White, J.C. Gower, and G.
Tunnicliffe-Wilcon. 1987. Genstat 5 Refference Manual. Oxford University Press, New York, 749pp.

Pinyopusarerk, K., A. Kalinganire, E.R. Williams, and K.M. Aken. 2004. Evaluation of International Provenance Trials of Casuarina sequisetifolia. ACIAR Technical Reports No. 58e, Canberra, 106 pp.

Rimbawanto A., N.K. Kartikawati, L. Baskorowati, M. Susanto and Prastyono. 2009. Status terkini pemuliaan Melaleuca cajuputi. Prosiding ekspose hasil-hasil penelitian Balai Besar Penelitian Bioteknologi dan Pemuliaan Tanaman Hutan, 1 Oktober, pp. 148-157.

Robinson, R. W., P.I. Boon and P. Bailey. 2006. Germination characteristics of Melaleuca ericifolia $\mathrm{Sm}$. (swamp paper bark) and their implications for the rehabilitation of coastal wetlands. Marine and Freshwater Research 57: 703-711.

Rosseto, M., R.W. Slade, P.R. Baverstock, R.J. Henry, and L.S.Slee. 1999. Microsatelite variation and assessment of genetic structure in tea tree (Melalenca alternifolia Myrtaceae). MolecularEcology 8: 633 -643.

Turnbull, J. and J. Doran. 1987. Seed development and germination in the Myrtaceae. In: P. Langkamp. P. (Eds.) Germination of Australian Native Plant Seed. Inkata Press, Melbourne, pp. 46 - 57.

Williams, E.R., A.C. Matheson and C.E. Hardwood. 2002. Experimental Design and Analysisfor Tree Improvement. Second edition, CSIRO Publishing, Australia, 214 pp.

Yamada, H., P. Tambunan, F. Mangkuwibowo, R.L. Hendrati and C. Osamu. 2001. Study on the prediction of seed production in seedling seed orchards of Acacia mangium and Eucalyptus pellita. FTIP-P2-No.28, JICA and FORDA, $65 \mathrm{pp}$.

Young, A., T. Boyle and T. Brown. 1996. The population genetic consequences of habitat fragmentation for plants. Trends in Ecology and Evolution 11 (10): 413-418. 